\title{
Is ISO 14001 certification really good to the company? a critical analysis
}

\author{
Aline Vomero Reis ${ }^{\mathrm{a}}$, Fábio de Oliveira Neves ${ }^{\mathrm{a}}$, Suzana Eda Hikichia*, Eduardo Gomes Salgado ${ }^{\mathrm{a}}$, \\ Luiz Alberto Beijo ${ }^{\mathrm{a}}$ \\ aUniversidade Federal de Alfenas - UNIFAL-MG, Alfenas, MG, Brasil
}

*suzanahikichi@gmail.com

\begin{abstract}
Paper aims: This paper aims to review the literature on the 150 14001, an international certification for manage of Environmental Management Systems through a critical analysis of the retrieved papers based on journals in three popular databases among Brazilian researchers.

Originality: The paper show the panorama of the ISO 14001 certification on companies presented in papers based in three databases with free access to the Brazilian academic community.

Research method: The present work was constructed through a critical analysis, carried out in two stages: a literature review and the discussion of the selected papers.

Main findings: Results showed that the benefits found by certified companies can be classified in internal, external and relations benefits. The impact of the certification on financial and organizational performances showed to be positive. Enhancement of internal processes, strengthening of results, prevention of potential problems and a larger number of stakeholders are pointed as important performance improvements.

Implications for theory and practice: Present the main concepts on the role of the ISO 14001 in companies, emphasizing the importance of the standard for company performance and providing a critical analysis on the standard that has been expanding in the international market.
\end{abstract}

\section{Keywords}

Environmental management. Environmental management systems. Financial performance. Organizational performance. 1509001.

How to cite this article: Reis, A.V., Neves, F.O., Hikichi, S.E., Salgado, E.G., \& Beijo, L.A. (2018). Is 1S0 14001 certification really good to the company? a critical analysis. Production, 28, e20180073. https://doi.org/10.1590/0103-6513.20180073

Received: Aug. 17, 2018; Accepted: Oct. 31, 2018.

\section{Introduction}

In the last centuries, with the advent of the industrial revolution and the expansion of human population, nature is no longer a recycler of wastes and has become an accumulator (Moreira 2004; Arana-Landin \& Heras-Saizarbitoria, 2011). Despite concerns about the environment are still not very significant, many mechanisms to contain and/or mitigate environmental pollution are being developed (Arana-Landin \& Heras-Saizarbitoria, 2011; Paulraj \& Jong (2011).

Among the actions promoted in order to control this environmental pollution is the global conference on the environment, held in 1972 in Stockholm that generated the report "The Limits to Growth", based on an overall balance through population growth (Souza et al., 2010; Arana-Landin \& Heras-Saizarbitoria, 2011; Paulraj \& Jong 2011). In 1987, it was held the World Commission on Environment and Development that generated the report "Our Common Future "which attempted to spread the term "sustainable development" and in 1992, with the advent of the United Nations Conference on Environment and Development, called Rio 92, authorities tried 
to consolidate the concept of sustainable development, bringing the importance of environmental management within enterprises (Feil et al., 2013). Also according Feil et al. (2013), the Business Council for Sustainable Development supported the creation of a specific committee, at International Organization for Standardization (ISO), to address the issues of environmental management. Hence, in March 1993, ISO established the technical committee 1SO/TC 207 whose work resulted in the development of the ISO 14000 series (Disterheft et al., 2012), based on the British standard BS/7750, which in turn was influenced by the environmental regulations of the European Commission, the Eco Management and Audit Scheme (EMAS). In this series, the only standard that is auditable is ISO 14001, granting a certificate of environmental management to organizations that adopt an Environmental Management System (EMS) in accordance with the standard (Disterheft et al., 2012). Through this EMS, it is possible to identify the various polluting activities, from the waste of energy and raw materials to the systematic organization of monitoring the environmental management system. Therefore, one of its main objectives is to promote balance between environmental protection and socio-economic needs (Yin \& Schmeidler, 2009).

Nawrock et al. (2009) reported that one of the main assumptions identified for the implementation of ISO 14001, besides the internal change regarding environmental sustainability, was the adequacy of substantial improvements that the organization could achieve on its various internal levels. In addition, Escanciano et al. (2001) also showed that the high organizational level of a company is also linked to the same type of implementation that ISO 9001 and ISO 14001 have. Also according to Escanciano et al. (2001), the benefits achieved with the ISO 14001 certification are not restricted to organizations and their employees, but extend to their customers as well.

Oliveira \& Serra (2010) and Heras-Saizarbitoria et al. (2013) also found that organizations seek to get certified to suit their respective laws, as ISO 14001 respects the peculiarities of each country. Thus, they seek to obtain a better acceptance of their products, as consumers envision a healthy company, with respect to environmental, economic and organizational sustainability. However, achieving these goals is a difficulty required by ISO 14001 in its pre- and post-implementation. Also, as pointed by Barkemeyer et al. (2015) regarding anti-corruption engagement, it can be seen that the fact that the company demonstrates its commitment to sustainability does not mean that it really is committed to these actions. A number of questions remain concerning the real benefits and difficulties of the implementation of ISO 14001 to various organisations and contexts. Based on that, it is necessary to conduct a study comparing papers results summarizing all these results. Thus, based on the reasons shown above, which were the subject of motivation for this work, an extensive literature review was conducted on articles published between 2005 and 2016 in order to answer the following questions:

1. What are the main benefits and difficulties in implementing ISO 14001 and being certified, for an organization?

2. What are the impacts on financial and organizational performance with the implementation of ISO 14001 ?

3. What is the relation between ISO 9001 and ISO 14001, since the standards share many similarities in their structure?

This paper is structured in five (5) sections: Introduction, a brief review of the literature, the research method used in this work, the results and discussions raised in this paper and, finally, the conclusions.

\section{Overview on ISO 14001}

ISO 14001 is the best known standard of the ISO 14000 series and specifies the requirements for any organization, of any type or size, to implement an EMS (Hikichi et al., 2016). Launched in September 1996, with a structure based on the ISO 9001 Quality Management Systems standard, the latest revision of ISO 14001 was held in 2015. The currently version of the 1SO 14001:2015 contains 10 sections, launched to facilitate its analysis and implementation. The Environmental Management System requirements are the most important point of EMS, which in turn, is structured on the concept of PDCA cycle (Feil et al., 2013). This structure of EMS enables organizations to develop an environmental policy, to improve their performance as needed and demonstrate compliance with the requirements of this standard (Souza et al., 2010; Gomez \& Rodriguez, 2011; Disterheft et al., 2012). It's important to highlight that the requirements of ISO 14001 need to be continually executed, by consequence the environmental operations and planning of the actions are being constantly improved (latridis \& Kesidou, 2018).

According to Heras-Saizarbitoria et al. (2011a), the EMS is a practical tool for environmental initiatives that may ultimately generate financial benefits through market competition or improvement of organizations: cost reduction and increase in revenue. These benefits have encouraged companies to adopt the ISO 14001 standard, 
which is the most popular environmental management standard nowadays, with more than 300,000 companies certificated worldwide (International Organization for Standardization, 2015), distributed unevenly around the world, with countries where stakeholders exert stronger pressure on the environmental impact of the firms being more likely to adopt the standard (Orcos et al., 2018).

\section{Research method}

The present work presents a literature review constructed through a critical analysis. A critical analysis consists of an exam of a body of literature, with a subjective selection of papers by the authors, in which the main ideas and concepts presented in the papers are discussed, without exhaustive discussion on the original concepts (Nakano \& Muniz Junior, 2018). The critical analysis was carried out in two stages. The first stage consists in a literature review, following the guidelines of Burgess et al. (2006). However, no statistical methods were applied, since all the relevant selected papers were accounted. The purpose of this review is to find what studies about ISO 14001 have covered the topics about benefits, difficulties and performance. The second purpose of this critical analysis is to find the relation between ISO 9001 and ISO 14001, since the standards share many similarities in their structure. A narrative overview is given way by the results of the critical analysis. This discussion of the papers, as a second step, is necessary to cover the main aspects of 1SO 14001 literature, looking for providing a critique, and even proposing a structure for future analysis (Nakano \& Muniz Junior, 2018).

The journals of interest were located by consulting CAPES (Higher Education Personnel Improvement Coordination) database of journals. The use of this database is justified because through CAPES, the Brazilian government offers the Publications Gateway, one of the greatest bases of quality scientific information with free access to the majority of national researchers. Additionally, we used SciELO and Google Scholar, considered as relevant databases to search for journal articles by Brazilian scientific community, to complement the search for journals in the period of 2005-2015. The search was limited to journals from 2005, since there was a change in the $1 \mathrm{~S} 014001$ standard in 2004, which made it relevant to analyze articles developed in this version. This is due to the interest of the research to evaluate the publications that occurred precisely with this review. This research will form the basis for future research to be carried out in the 2015 version of the standard.

The keywords used for the search were: "ISO 14001 and organizational performance"; "ISO 14001 and financial performance" and "Relation ISO 14001 and ISO 9001". A conceptual map was developed based on the data collected (Figure 1). The map also shows the subjects that will be developed in this work.

The tables used by Godinho-Filho \& Fernandes (2003, 2004), Carnevalli \& Miguel (2007), Godinho-Filho et al. (2009) and Salgado et al. (2010) were adapted to carry out the work filing.

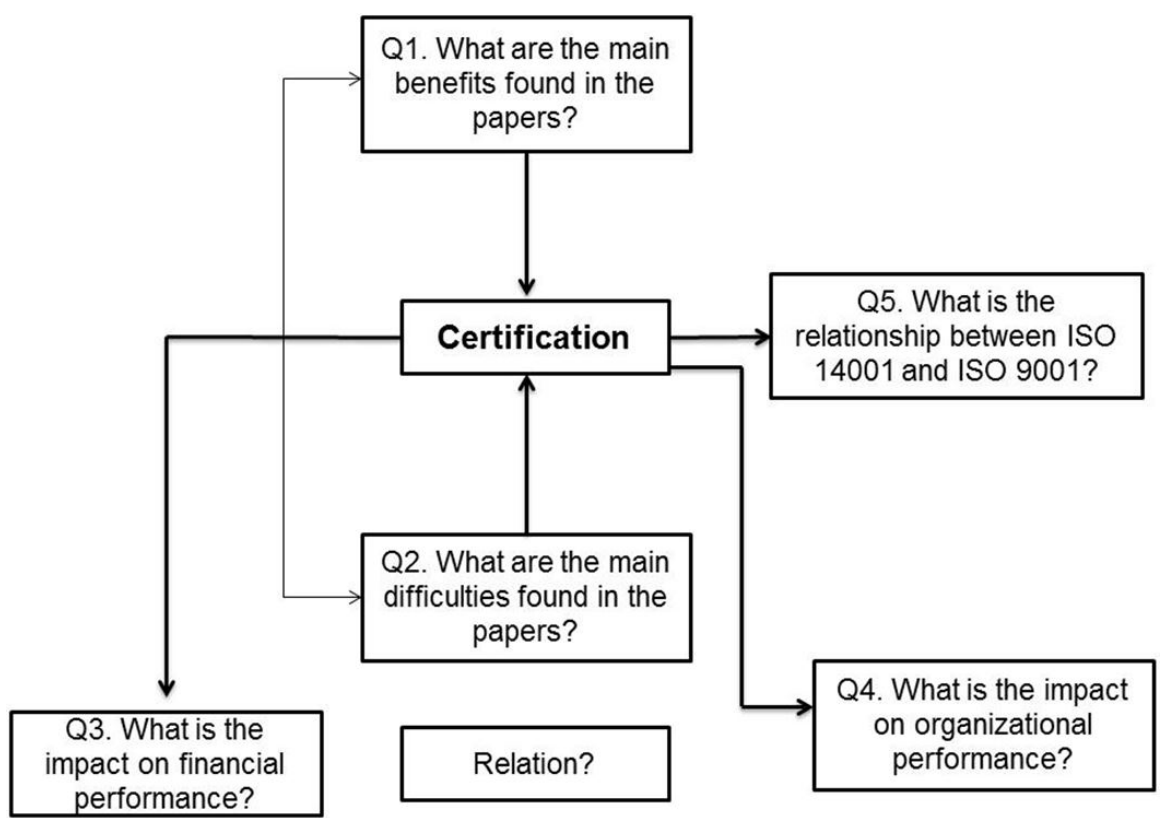

Figure 1. Main issues identified (methodology). Adapted from Godinho-Filho et al. (2009) and Salgado et al. (2010). 


\subsection{Identification and codification of journals}

The evolution of the number of publications over the period analyzed of the 117 journals selected and coded was analyzed, according with the keywords applied. The journal that had the largest number of publications on this subject was the "Journal of Cleaner Production", whose publications increased since 2010, showing the continued need for research on this topic. Also, it was noted that the studies were not restricted to just one location, with Europe carrying most of the studies, despite Asia having the largest number of certificates among the continents.

\section{Descriptive analysis}

This section will present and discuss the results found in the analysis of the selected journals.

\subsection{Key benefits and difficulties}

Most scientific studies analyzed did not mention the reasons that led companies to get certified, but only the benefits and difficulties encountered in the implementation. In this sense, the benefits and difficulties can be categorized as internal and external. The internal benefits are related to the achievement of organizational improvements with respect to this environment, while the external benefits are related to obtaining improvements in the company image level, marketing, market and customers. The internal difficulties are related to the costs and obstacles to the implementation of the standard, and, the external difficulties, related to legislation and government actions.

\subsubsection{Benefits}

Some positive points for companies acquiring an EMS based in the ISO 14001 are cited by Psomas et al. (2011) as minimizing environmental liabilities, maximizing the efficient use of resources, reducing waste, corporate image, building environmental awareness among employees, better understanding of environmental impacts among the employees and business activities, and increase in profits through more efficient operations. Figure 2 shows all the benefits cited in the papers studied.

Tari et al. (2012) pointed out three different groups of benefits, as follows: internal benefits (organizational improvement, environmental performance, and costs), external benefits (image and markets) and relations benefits (environmental awareness, competitiveness and customers). Link \& Naveh (2006) distinguish between

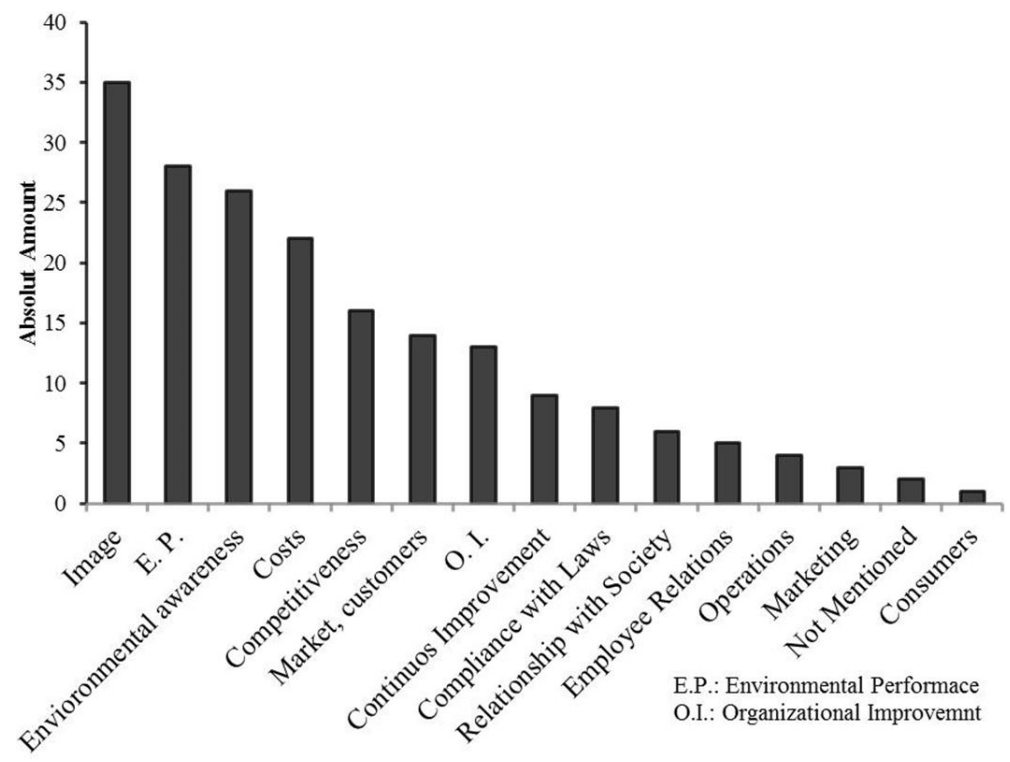

Figure 2. Benefits pointed for ISO 14001 certification in the studied journals. 
environmental performance (environmental performance and environmental awareness) and business performance (image, costs, competitiveness, organizational improvement, market and customers). Gavronski et al. (2008) emphasize four benefit groups: productivity benefit (organizational improvement), financial benefit (costs), market benefit (competitivity, market and customers) and social benefit (image, environmental performance and environmental awareness). Table 1 shows an overiew of the benefits pointed by the authors and in which papers they were cited.

Table 1. Benefits pointed for ISO 14001certification and their respective literature.

\begin{tabular}{ll}
\hline Benefit & Definition \\
\hline & \\
Image & Positive image of the company in obtaining \\
& 1SO 14001 certification
\end{tabular}

Aiyub et al. (2009), Nishitani (2009), Grael \& Oliveira (2009), Turk (2009),

Yin \& Ma (2009), Turner (2009), Ziegler \& Seijas Nogareda (2009), Heras-

Saizarbitoria \& Arana (2010), Oliveira \& Serra (2010), Oliveira et al. (2010), Santos et al. (2011), Marimon et al. (2010), Campos (2012), Whitford \& Tucker (2012), Santos et al. (2012), Tarí et al. (2012), Agan, et al. (2013), Zhang et al. (2013), Seijo-García et al. (2013), Castka \& Prajogo (2013), Kadasah (2013), Zobel (2013), Schylander \& Martinuzzi (2007), Sambasivan \& Fei (2008), Alemagi et al. (2006), Lagodimos et al. (2007), Tan (2005) and Zeng et al. (2008)

Nishitani (2009), Matuszak-Fleijsman (2009), Turk (2009), Iraldo et al. (2009), Ziegler \& Seijas Nogareda (2009), Oliveira et al. (2010), Heras-Saizarbitoria \& Arana (2010), Sakr et al. (2010), Oliveira \& Serra (2010), Oliveira et al. (2010),

Environmental Improvement of the company's environmental Performance

Environmental Awareness

Cost

Competitiveness

Market

Organizational Improvement

Compliance with Laws

Relationship with Society

Employee

Relations

Operations

Marketing

Consumers

Customers

\section{performance with ISO 14001 certification}

Changes in the company's internal culture with 1 SO 14001 certification

Improvement of the environmental and economic costs with 1SO 14001 certification

Increased competitiveness of the company with 1 SO 14001

Improvement in green marketing for new customers

Improvement of the company's performance with the 1SO 14001 standard, since both ISO 9001 and $1 S 014001$ standards are identical.

ISO 14001 implementation needs to follow the legislation of the country where the company is located.

The emission of certificates of compliance with the norm and independent bodies allows the society to perceive the environmental concern.

Dependence and commitment among employees to allow to implement 1SO 14001 Internal operations of the company to measure environmental measures. Use of environmental marketing after obtaining the ISO 14001 Standard Increase in the number of consumers of the companies after obtaining the environmental certification.

Increase in the number of customers as a result of the green seal
(2011), Paulraj \& Jong (2011), Guoyou et al. (2012), Santos et al. (2012), de Vries et al. (2012), Prajogo et al. (2012), Granly \& Welo (2013), Kadasah (2013), Nguyen \& Hens (2013), Silveira et al. (2013), Alemagi et al. (2006), Newbold (2006), Fortuński (2008), Eng Ann et al. (2006) and Zeng et al. (2008)

Turk (2009), Oliveira \& Pinheiro (2009), Franchetti (2011), Psomas et al. (2011) Guoyou et al. (2012), Ferron et al. (2012), de Vries et al. (2012), Prajogo et al. (2012), Granly \& Welo (2013), Seijo-Garcia et al. (2013), Kadasah (2013), Nguyen \& Hens (2013), Alemagi et al. (2006), Newbold (2006), Fortuński (2008), Eng Ann et al. (2006) and Zeng et al. (2008)

Grael \& Oliveira (2009), 1raldo et al. (2009), Oliveira \& Serra (2010), Oliveira \& Pinheiro (2009), Ratnasingam \& Wagner (2010), Oliveira \& Serra (2010), Massoud et al. (2010), Oliveira et al. (2010), Paulraj \& Jong (2011), Rodriguez et al. (2011), Santos et al. (2012), Ferron et al. (2012), Tarí et al. (2012), Zhang et al. (2013), Castka \& Prajogo (2013), Gavronski et al. (2008), Alemagi et al. (2006), Eng Ann et al. (2006) and Zeng et al. (2008) Aiyub et al. (2009), Kehbila et al. (2009), Tsai \& Chou (2009), Zeng et al. (2005), Takahashi \& Nakamura (2010), Oliveira et al. (2010), Brendler \& Brandli (2011), Borella \& Naime (2012), Whitford \& Tucker (2012), Santos et al. (2012), de Vries et al. (2012) and Gavronski et al. (2008).

Jurincic \& Bojnec (2009), Cañón-de-Francia \& Garcés-Ayerbe (2009), Aiyub et al. (2009), Sakr et al. (2010), Oliveira \& Pinheiro (2009), Nishitani (2009), Psomas et al. (2011), Prajogo et al. (2012), Agan et al. (2013), Gavronski et al. (2013) and Schylander \& Martinuzzi (2007) Nishitani (2009), Oliveira \& Serra (2010), Oliveira \& Pinheiro (2009), Oliveira \& Serra (2010), Santos et al. (2011), Brendler \& Brandli (2011), Simon et al. (2011, 2012), Gavronski et al. (2013), Kadasah (2013), Halila \& Tell (2013) and Sambasivan \& Fei (2008)

Turner (2009), Oliveira \& Serra (2010), Heras-Saizarbitoria \& Arana (2010), Oliveira \& Pinheiro (2009), Zeng et al. (2008), Heras-Saizarbitoria et al. (2011a) and Silveira et al. (2013)

Simon et al. (2011), Santos et al. (2012), Tarí et al. (2012), de Vries et al. (2012), Prajogo et al. (2012), Seijo-García et al. (2013) and Gavronski et al. (2008)

Matuszak-Fleijsman (2009), Oliveira et al. (2010), Rodriguez et al. (2011), Simon et al. (2012) and Sambasivan \& Fei (2008)

Oliveira \& Serra (2010), Simon et al. (2011), Franchetti (2011) and Tan (2005)

Massoud et al. (2010) and Zeng et al. (2008)

Alemagi et al. (2006)

Matuszak-Fleijsman (2009), Kehbila et al. (2009), Yin \& Ma (2009), Oliveira \& Pinheiro (2009), Oliveira \& Serra (2010), Zeng et al. (2008), Granly \& Welo (2013), Halila \& Tell (2013), Sambasivan \& Fei (2008) and Gavronski et al. (2008) 
All these types of benefit classifications are only a mechanism for organizations to improve their environmental and business performances (Psomas et al., 2011). They help by minimizing environmental performance, in the reduction of costs, improving the image with the public, in the prevention and reduction of pollution and markets. Hwee-Nga (2009) stated that the existing literature has documented the perception that ISO 14001 certification leads to increased competitive advantage, regulation, increased financial performance and improved reputation and reduced cost of business.

Certified companies have a natural way after adequacy and consolidation of the ISO 9001 quality management model, which is the adoption of the quality awards for excellence model (Oliveira \& Martins, 2008). According to Yin \& Schmeidler (2009), companies certified to ISO 14001 in their daily operations are more likely to report improvements in the environment. Environmental improvements are also more likely to occur in facilities that include performance management elements in their ISO 14001.

The certification is beneficial to the company because it shows that it has environmental awareness, which contributes to a good image to consumers, helping the company's competitiveness in the market. As Hojnik \& Ruzzier (2017) stated, ISO 14001 affects positively benefits as competitiveness, which means that companies that are ISO 14001 certificated have their competitiveness improved. In addition, the certification helps develop preventive environmental actions, such as reducing the consumption of oil, energy, water, gas and fuel, as well as a positive influence on other internal management processes (Govindan et al., 2014).

Other studies suggest a broader classification, including interpersonal, operational, customer and financial benefits relations, which in turn can be divided into internal and external. According to these studies, internal benefits include improvements in internal processes of the companies, which have positive effects on operational and people issues, such as increasing productivity, improving efficiency and reducing waste and training costs. External benefits are related to effects on customers and society in general, such as customer satisfaction, better relations with stakeholders and improved image. In this context, some studies classify financial results as external benefits while others as internal benefits (Simon et al., 2011; Tarí et al., 2012; Stevens et al., 2012).

Consequently, in this context, both patterns show clear benefits on certain issues, such as organizational improvement, competitiveness, market and customers, which indicate that, in general, certified companies improve their operations, employee relations and stakeholder's performance. However, only a few certified companies show improvement compared to non-certified companies, with respect to finances, showing that there is no impact on financial performance. So, although the standards create internal and external benefits many of them have a positive effect on people, operational issues and stakeholders, the relationship between these standards and financial performance are not as clear (Tari et al., 2012).

Third, several studies have shown that internally motivated companies improve their internal and external performance results (Stevens et al., 2012; Heras-Saizarbitoria et al., 2011a; Seijo-García et al., 2013; Tari et al., 2012). This idea was suggested by the view of some authors in the papers analyzed, which tried to explain the relation between the two situations. In this context, these papers show that companies seeking certification only, also reach some benefits. However, when a company is motivated and really strives to implement the Environmental Management System ISO 14001, with a real commitment to the environment, i.e. when the standards are internalized, the possibility of achieving all the benefits listed is much higher (Seijo-García et al., 2013; Tarí et al., 2012).

William McGuire (2014) shows strong evidences of a causal relationship between the ISO 14001 certification and compliance with environmental standards. The author showed that certified companies have the highest number of compliance with all relevant environmental standards and consequently violation reports of environmental standards have decreased, strengthening the image of these companies to the market and gaining consumer public. This effect persists when using a valid set of tools to implement the standard and control the endogeneity. This is the first evidence at the company level that the rapid adoption of ISO 14001 can help promote the compliance with environmental standards. The results also reinforce the pattern observed in the literature on ISO 14001, which identifies a positive causal effect of ISO 14001 on environmental performance.

\subsubsection{Difficulties}

By implementing the ISO 14001 EMS, there is a positive relation of the certified company, regarding environmental issues, its suppliers and the local community, featuring that environmental concern is spread both around and inside the company (González et al., 2008). The main difficulty related to ISO 14001 certification for businesses is the cost, as for the implementation of the standard, companies have to undertake large investments, outside their pattern, and in the case of Brazil a factor of great impact for the adoption of certification are the constant changes in environmental legislation (Zeng et al., 2008). 
Analyzing the results obtained by some companies after certification, mixed results are found, i.e. while there are improvements in industrial performance, these improvements are not that relevant for the initial expense (Castka \& Balzarova, 2008). Another downside on the implementation of ISO 14001 are the inflated expectations generated at the time of implementation, there is a large initial cost and the improvements, from the standard, only cover this initial cost (Heras-Saizarbitoria et al., 2011b). The difficulties pointed by the authors in the analyzed journals are shown in Figure 3 and an overview with the difficulties pointed by the authors can be seen in Table 2 .

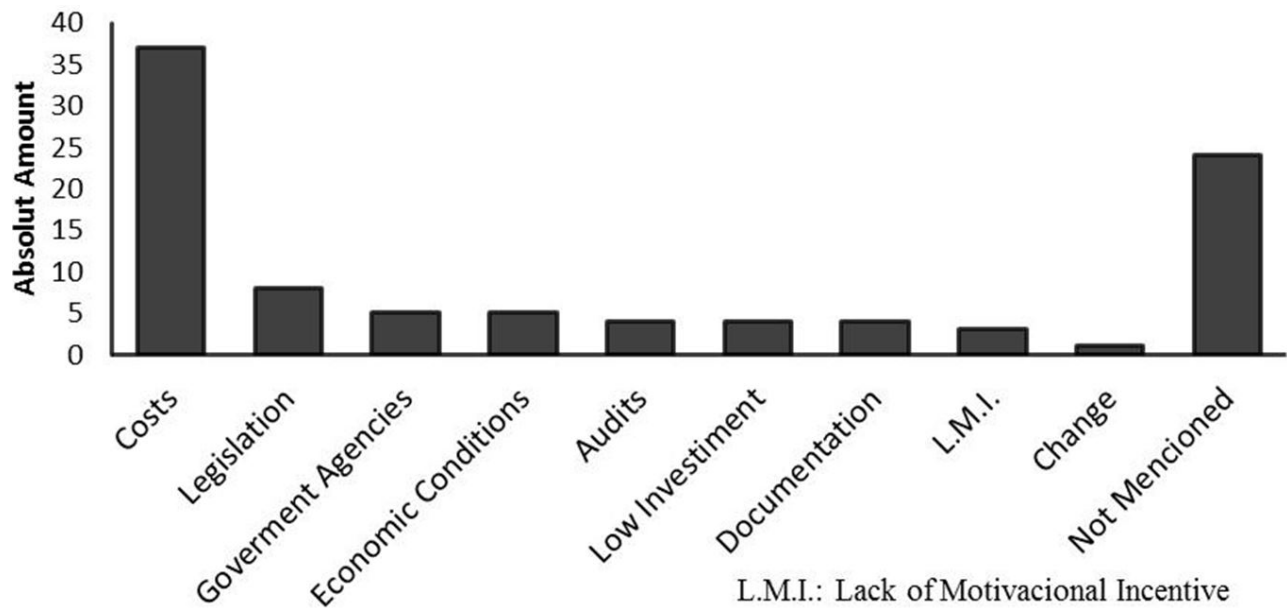

Figure 3. Difficulties pointed for ISO 14001certification in the journals studied.

Table 2. Difficulties pointed for ISO 14001 certification and the respective literature.

\begin{tabular}{|c|c|c|}
\hline Difficulties & Definition & Literature \\
\hline Costs & Costs for the norm implementation & $\begin{array}{l}\text { Jurincic \& Bojnec (2009), Cañón-de-Francia \& Garcés-Ayerbe (2009), } \\
\text { Aiyub et al. (2009), Kehbila et al. (2009), lraldo et al. (2009), Turner } \\
\text { (2009), Oliveira \& Serra (2010), Oliveira et al. (2010), Heras-Saizarbitoria } \\
\text { \& Arana (2010), Heras-Saizarbitoria et al. (2013), Oliveira \& Serra } \\
\text { (2010), Zeng et al. (2008), Chan (2010), Marimon et al. (2010), Brendler } \\
\text { \& Brandli (2011), Borella \& Naime (2012), Simon et al. (2012), Whitford } \\
\text { \& Tucker (2012), Ferron et al. (2012), Tarí et al. (2012), de Vries et al. } \\
\text { (2012), Gavronski et al. (2013), Seijo-García et al. (2013), Kadasah } \\
\text { (2013), Zobel (2013), Alemagi et al. (2006), Lagodimos et al. (2007) and } \\
\text { Eng Ann et al. (2006) }\end{array}$ \\
\hline Legislations & $\begin{array}{l}\text { Constant changes in countries' environmental } \\
\text { standards }\end{array}$ & $\begin{array}{l}\text { Oliveira \& Serra (2010), Oliveira et al. (2010), Oliveira \& Serra (2010), } \\
\text { Agan et al. (2013), Silveira et al. (2013), Schylander \& Martinuzzi (2007) } \\
\text { and Zeng et al. (2008) }\end{array}$ \\
\hline $\begin{array}{l}\text { Governament } \\
\text { Agencies }\end{array}$ & $\begin{array}{l}\text { Difficulties imposed by government agencies as a } \\
\text { result of the laws in the countries }\end{array}$ & $\begin{array}{l}\text { Aiyub et al. (2009), Oliveira \& Serra (2010), Heras-Saizarbitoria \& Arana } \\
\text { (2010), Oliveira \& Serra (2010), Bernardo et al. (2012), Agan et al. } \\
\text { (2013) and Halila \& Tell (2013) }\end{array}$ \\
\hline $\begin{array}{l}\text { Economic } \\
\text { Conditions }\end{array}$ & $\begin{array}{l}\text { Companies with economic difficulties to } \\
\text { implement the } 1 S 014001 \text { standard }\end{array}$ & $\begin{array}{l}\text { Oliveira \& Pinheiro (2009), Sakr et al. (2010), Simon et al. (2011), } \\
\text { Rodriguez et al. (2011) and Halila \& Tell (2013) }\end{array}$ \\
\hline Audits & $\begin{array}{l}\text { Accomplishments of constant audits to keep 1SO } \\
14001 \text { certification up to date }\end{array}$ & $\begin{array}{l}\text { Oliveira \& Serra (2010), Massoud et al. (2010), Halila \& Tell (2013), } \\
\text { Silveira et al. (2013) }\end{array}$ \\
\hline Low Investiment & $\begin{array}{l}\text { Difficulties in obtaining investments by } \\
\text { companies to meet the requirements of } 150 \\
14001\end{array}$ & Turner (2009), Tsai \& Chou (2009), Alemagi et al. (2006) \\
\hline Documentation & $\begin{array}{l}\text { Difficulty in recovering all the documentation } \\
\text { involved in obtaining environmental cycles }\end{array}$ & Brendler \& Brandli (2011) and Zeng et al. (2008) \\
\hline $\begin{array}{l}\text { Lack of } \\
\text { Motivacional } \\
\text { lncentive }\end{array}$ & $\begin{array}{l}\text { Lack of senior management incentive with } \\
\text { employees to meet 1SO } 14001 \text { certification } \\
\text { requirements }\end{array}$ & Chan (2010) and Zeng et al. (2008) \\
\hline Cultural Change & $\begin{array}{l}\text { Changes in the company's internal culture with } \\
\text { the implementation of 1SO } 14001\end{array}$ & Simon et al. (2011) \\
\hline
\end{tabular}


However, in relation to the difficulties of ISO 14001 certification, there are few works that have studied the consequences of certification, and these studies are more focused on certification basis within the company. Oliveira \& Serra (2010), in their study on companies in the state of São Paulo, identified the costs for implementing the standard as one of the difficulties, as observed in this study. According to them, in the implementation and management of an EMS based on ISO 14001, some investments are common and contribute to increase in business costs, such as: adequacy of the organizational structure, intensification of training, development of awareness programs, modernization of equipment and the establishment of audits among others. As well as periodic changes in environmental legislation that make it difficult to update and comply with ISO 14001, as listed in the legislation and governmental actions.

The major resistance to the implementation of the standard is internal, related to the adjustment of employees to the requirements proposed by ISO 14001, as plant employees, particularly in the industrial sector, need to change some aspects of their routine to meet certain requirements, such as prevention and pollution control (Oliveira \& Pinheiro 2009). According to Psomas et al. (2011), managers continue to face resistance and challenges to implement and carry out maintenance of systems/standards, whether they are of quality, occupational health and safety, environmental or any other area. Chavan (2005) stated that although the ISO 14001 standard was created to help organizations, there are some factors that can prevent a company from successfully implementing an EMS, such as the unavailability of staff, who can oppose the increase of responsibilities; administration's reluctance to give the time and resources needed to implement the EMS, and the belief that once the EMS is installed, it does not need to be constantly revised and improved (Psomas et al., 2011; Chavan, 2005).

Eng Ann et al. (2006) noted that bureaucracy and unnecessary documentation would be a disadvantage for the implementation of ISO 14001. Liyin et al. (2006) reported that increased costs and the consumption of time and resources to implement the ISO 14001 certification discourage construction companies to actively participate in improving their environmental performance. According to Psomas et al. (2011), one of the main obstacles to the implementation of the standard is the total cost and, more specifically, the long-term establishment of the standard and its constant improvements.

Turk (2009) mentions that the disadvantages of obtaining ISO 14001 include high initial and operating costs, lack of qualified personnel and communication on the certificates. Granly \& Welo (2013), studying experiences in the implementation of the standard in Norwegian business processes, observed difficulties as time for implementation and use of the standard and performance with environmental/quality aspects, training and commitment. Simon et al. (2012) studying Spanish companies, found that between the difficulties encountered were the high cost, difficulty to implement the standard and internal organization.

\subsection{Impact on organizational performance}

The research conducted in this study also aimed to check the impact of 15014001 certification on business performance. Most studies concluded that there is a positive relation between the implementation of ISO 14001:2004 practices and organizational performance.

From 117 studies surveyed, 56 showed a positive relation to organizational performance, 31 studies did not mention relation, 8 had a negative impact and 3 said it has no influence.

Studies provide evidence that facilities that assimilated ISO 14001 in their operational routine to a greater extent are more likely to report greater improvement of environmental performance after certification and more likely to report that ISO certification contributed to organizational improvement, to a greater extent, compared with those who had a lower level of integration (Yin \& Schmeidler, 2009).

According to Oliveira et al. (2010), ISO 14001 provides the improvement of various internal processes facilitating and improving organizational performance, being an example of fuel, oil and natural gas economy. In addition to widely avoiding known basic errors, the standard also strengthens results and anticipates the solving of potential problems.

The certification attracts larger number of stakeholders (investors) due to the dynamic nature of the social and environmental responsibility of companies to be able to select and execute a good strategy, so with greater investment development is directly affected positively (Hayam, 2010).

In research works dedicated to impact analysis of the implementation of the Environmental Management System based on ISO 14001 in organizations, there are specific studies dedicated to this type of research: Ratnasingam \& Wagner (2010) found that, despite the high cost to implement environmental certification, companies that have this type of standard report a positive organizational performance, as they put into practice techniques and cultures that contribute to the cost-benefit ratio on organizational performance and the environment. 
In turn, de Vries et al. (2012) observed that the positive impacts are influenced by the operating age of the EMS based on ISO 14001 implemented, in addition to the following factors: company's management commitment, size of the organization, delegation of tasks and responsibilities, training, awareness and involvement of employees and participation of stakeholders. Agan et al. (2013) found a positive relation between cooperation agreements among small and medium-sized companies that had ISO 14001 and their organizational performance, driving the growth of these organizations.

Studies on ISO 14001 as Link \& Naveh (2006) pointed out that, for this pattern to be truly effective, a part of the daily verification work of the standard must be done. The authors measured the degree of standardization, considering the level of policies and procedures in which ISO 14001 govern the management of environmental issues within organizations. Using six items from Naveh et al. (2005), Schylander \& Martinuzzi (2007) pointed out that in the development of an ISO 14001 EMS for a sustainable management system in the performance of organizations, the two most important challenges are to improve the coordination between the organization's strategies and synchronize organizations with competitors' core value. Tari et al. (2012) emphasize that environmental management must be integrated into the organizational strategic planning process. Yin \& Schmeidler (2009) indicate that standardized management systems can be implemented in very different ways in various organizations. According to these researchers, this variability in the implementation may be responsible for the heterogeneous standardized performance of these systems, and the current literature on the environmental impacts of ISO 14001 certification largely disregard this phenomenon. The authors also highlighted the integration of 1SO 14001 for daily operations, as well as the inclusion of performance management elements of ISO 14001 .

Moreover, since institutional investors can recognize the investment in social and environmental responsibility as a possible alternative to reduce management discretionary power, a promising area for research in future studies is the relation between the mechanisms of corporate governance and corporate social and environmental responsibility. Internal and external governance mechanisms, such as lenders, board leadership structure, size and composition are now out of the spotlight of research (Hayam, 2010).

\subsection{Impact on financial performance}

In the studied journals, the impact of the implementation of ISO 14001 on financial performance was appointed as positive in 56 papers, while six others indicated a negative impact. Figure 4 shows the data collected. The benefits cited related to improving productivity and consequently the impact on organizational and financial performance would influence the image, cost, competitiveness, organizational improvement, market and customers.

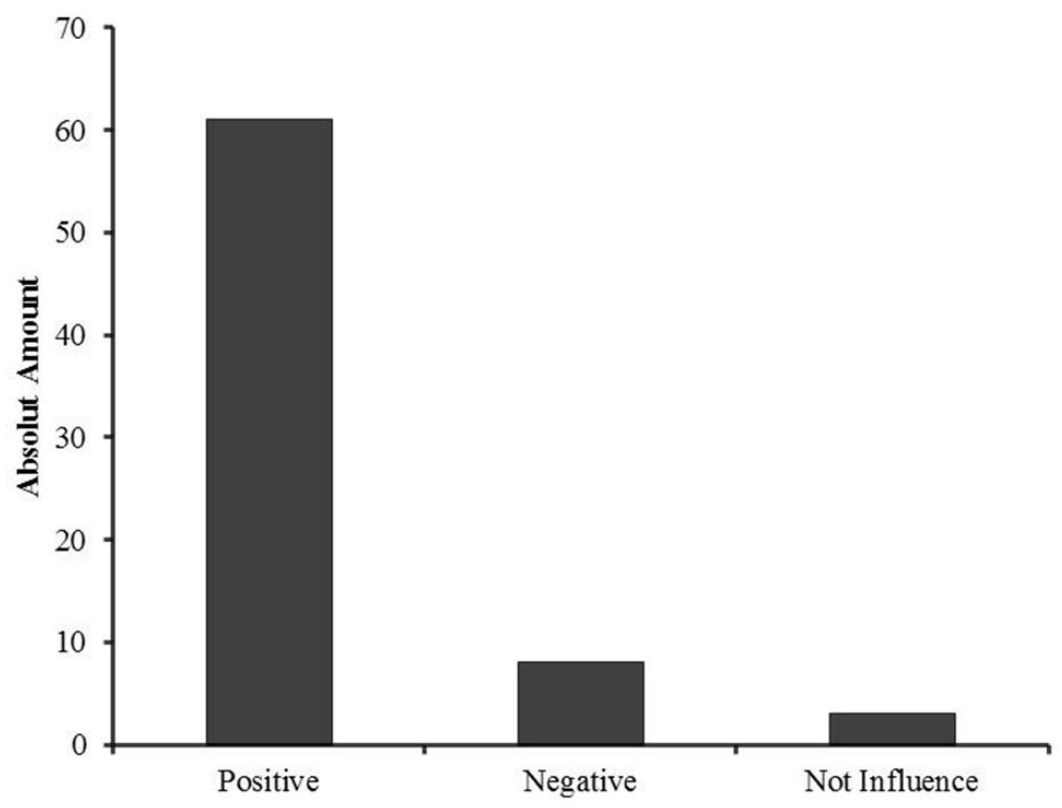

Figure 4. Influence of ISO 14001 on organizational performance. 
According to Lagodimos et al. (2007), having certification is a positive aspect for the company, since with an efficient environmental management the industrial sector achieves greater market penetration, and thus more effective profitability. Studies have argued that institutional investors can use social and environmental responsibility of companies as a tool to protect the value of their investment, by legitimizing existence and operations in accordance with industry standards or decreasing the managerial entrenchment, i.e. the ISO 14001 certification can interfere in equity value (Hayam, 2010).

As showed by Heras-Saizarbitoria et al. (2011a), expectations about the impact of 1SO 14001 certification on improved financial performance may exist, since studies have shown that the money spent on certification did not harm the profitability of the companies, because the benefits arising from certification costs are, on average, sufficient to offset the implementation investment, so they do not bring harm and will bring long-term profits. Heras-Saizarbitoria \& Landín (2011), in a longitudinal quantitative study, showed that companies with better financial performance are more likely to implement the ISO 14001 standard, and this is due probably to the fact that these companies already have capital reserves for investments of the image in the market in order to attract new customers and investors.

According to de Vries et al. (2012), competitiveness skewed to profit is closely linked to the time the environmental certification is implemented in the company: The top management commitment, employee motivation, organization size, definition of responsibilities, training and employee engagement, employee awareness and participation of stakeholders are factors that have great influence on the financial performance in companies with environmental certification.

When looking at the causal link between the financial and the social business performance, corporate responsibility becomes a consistent platform for the specific case of ISO 14001. Preston \& O'Bannon (1997) termed this relation as "Available Hypothesis Funds" in which the availability of clearance allows a company, in the exercise of environmental and social activities, to make its products available at a higher price (Heras-Saizarbitoria et al., 2011b). Thus, this relation is considered consistent enough that the most profitable companies have greater propensity to adopt international standards such as EMS (s) based on ISO 14001.

King et al. (2005) and Potoski \& Prakash (2005) formulated, respectively, the theories of decentralized institutions and of cartels and clubs applied to volunteer programs, which can be used to explain the symbolic value of certification to attract better financial performance for companies.

According to Eng Ann et al. (2006), ISO 14001 has a positive impact on the financial performance of Malaysian companies. ISO 14001 adds value to EMS, even in a mature market like the Asian country, in addition to an ongoing continuous improvement activity. The authors also report that when companies do not realize an opportunity to use this marketing platform, they may lose a large share of the domestic market.

In contrast, the results presented by Paulraj \& Jong (2011) suggest a negative result. Their studies show that shareholders' wealth was reduced due to the certifications. This discrepancy has many implications. In practice, it suggests that companies need to educate shareholders about their actions to improve the environment. This coordinated bidirectional communication also ensures that ISO 14001 is highly regarded, widely adopted, and even requested by the shareholders.

\subsection{Relations between ISO 14001 with ISO 9001}

Continuing this research, the relation between the ISO 9001 quality management standard and the ISO 14001 certification was also assessed in order to verify whether there are implications in adopting the two standards and how ISO 9001 affects on ISO 14001 in companies that have both certifications. From the 117 papers surveyed, it was found a positive relation between the certifications, with 35 studies reporting a positive effect when implementing the quality management system (ISO 9001) as regard to environmental certification (ISO 14001). Only two studies reported negative effects and the remaining 61 did not mention the relation between ISO 14001 and 1SO 9001.

According to Lagodimos et al. (2007), the industrial sectors with the two certifications have competitive advantage over other companies, since they have better profitability. However, the certifications for ISO 14001 and ISO 9001 can be treated not only as tactics to improve business performance, but also as standardization of social responsibility, as ISO 14001 regard environmental improvement and sustainability (Castka \& Balzarova 2008).

Despite many positive points, studies show that in relation to the implementation system and internal inspections, the implementation of these management tools (ISO 9001 and ISO 14001) may be far from homogeneous and unambiguous. Organizations can adopt the same management tools in response to various institutional pressures and, therefore, become more isomorphic, this growing isomorphism can only be an external phenomenon (Yin \& Schmeidler 2009). Tari et al. (2012), in their literature review study on the benefits of ISO 9001 and 14001 
report that most studies that analyze the advantages of certification consider a dichotomous variable to see if the company is really certified, however, they do not analyze the degree of commitment, the implementation, or the internalization of the standards.

Also according to Tarí et al. (2012), many measuring quality management studies use and have used a variety of practices to determine a multidimensional construction, such as leadership, people management, customer management, supplier relationships, process management and information and analysis. According to the authors, these parameters are measured in a sample for each item, so the authors have notoriety to analyze whether a higher level for quality management is higher than the other.

With regard to environmental management, according to the authors mentioned above, there are studies that measure the degree of environmental proactivity using various practices and critical factors for the implementation. These issues have been little addressed in the case of ISO 9001 and ISO 14001 (Tari et al., 2012).

These same authors conclude in their study that there are many similarities between the quality and environmental systems, such as the purpose and the factors related to the implementation. Considering these parallels, quality management research would be more developed than environmental management and, consequently, the most significant benefits tend to be found in quality management (Tarí et al., 2012).

The impact of the economic crisis of recent years has had major negative effect on certifications (ISO 9001 and ISO 14001) a fact that can be analyzed and discussed through the ISO database itself (Marimon et al., 2009; Heras-Saizarbitoria et al., 2013). Comparison between countries with a higher competitiveness index as Germany and Finland, in relation to countries with lower competitiveness as ltaly, Spain and lsrael shows that certifications in less competitive sites were higher since the change of the standard in 2004 (Heras-Saizarbitoria et al., 2013).

Concerning the integration between environmental and quality systems, according to Arifin et al. (2013), the most successful organizations benefit from the integrality of the systems because they are well designed and operational. The organizational structure, personal responsibility, training, awareness and competence of those involved, communication, documentation, control documents, operational control and feedback are the main elements that influence the successful implementation of an integrated management system.

In other studies, it is found that organizations that have an integrated system for both managements (ISO 14001 and ISO 9001) experience greater benefit from the application of ISO 9001. And by comparing organizations with ISO 9001 and ISO 14001, significant statistical differences were found, with a greater proportion to those with an organizational management system. And yet, the existence of synergy can lead to eventual success and subsequent dissemination of the certifications integrated management system standards (Casadesús et al., 2009).

Zeng et al. (2008), when analyzing the Integrated Management System in China, found that the main reasons for implementation were satisfaction and requirement of customers, respond to government inquiries and deal with customer stress, and the benefits were simplify the process of certification, management and reduction of costs and the reduction of paper work. Simon \& Douglas (2013) in his six case studies in England and Spain outlined the benefits in the integration of management systems (ISO 9001 and ISO 14001), detecting significant differences in some aspects or stages during the process of integration. The most significant benefits were internal, simplification of tasks, increased organizational efficiency, better use of audit and improvement in organizational culture; and the external benefits were improving corporate image and greater involvement of stakeholders (Simon \& Douglas, 2013).

According to Simon \& Douglas (2013), the difficulties encountered were lack of human resources, lack of employee motivation and the differences of implementation models of an integrated management system. In the case of implementation strategy, according to Zeng et al. (2008), Griffith \& Bhutto (2008), Karapetrovic \& Casadesús (2009), Bernardo et al. (2009), Santos et al. (2011) and Simon \& Douglas (2013), we must first implement the ISO 9001 Quality Management System and then implement the Environmental Management System based on ISO 14001. And, though not always the company integrated the two systems, it was observed that there was a learning process in their routines (Brendler \& Brandli, 2011).

Crowder (2013) analyzed the factors that determined a successful integration between the environmental and quality systems, which are the support to senior management, coordination within the organization, leadership, smartness and appropriate approach.

\subsection{Is $1 \mathrm{SO} 14001$ certification really good to the company?}

The major difficulty related to ISO 14001 certification for businesses is the cost for the implementation of the standard, as extensively related in literature. In the implementation, several costs are required in order of improve the organizational structure, training and modernization of equipment, among other changes. However, it can be seen that the benefits of implementing the ISO 14001 standard far outweigh the difficulties encountered in 
this process. Studies showed that the impact on environmental performance after certification in facilities that assimilated ISO 14001 in their operational routine was likely to be positive, as the impact on financial performance and organizational performance, which would contribute to their organizational growth and competitiveness. Also, according to Ferrón-Vílchez (2016), concerning environmental performance, companies characterized by adopting ISO 14001 and, at the same time, monitoring their environmental activities are more likely to have improvements in their impact on the environment than companies that align the adoption of the standard and a low monitoring or do not adopt ISO 14001 and manage the environmental monitoring.

\section{Final considerations}

ISO 14001 is a certification that ensures that a company has an environmental management system with a developed structure. Thus, this organization can consistently control its significant impacts on the environment and continually improve operations and business.

Taking into consideration all the information gathered in this literature review, we can state that ISO 14001 certification is a trend. Studies have shown that certified companies are usually companies already established in the market and have economic power, even so, they seek ISO 14001 certification because they are sustainable aware and willing to attract new customers, new investors, and to improve the company's image among other benefits pointed out by the studies.

The benefits found by certified companies in this literature review show that they can be classified into three categories: internal benefits that are those who have demonstrated: organizational improvement, environmental performance and reduced costs with raw materials; external benefits that are improved image, expansion of consumer and investor market; and relations benefits that are environmental awareness, competitiveness and customers.

However, it was possible to identify that there are difficulties to implement the standard: financial difficulty, in the initial investment there is change, adjustments, training and awareness of all active employees in the company, and some countries suffer with the disadvantage of constant changes in legislation, a factor that negatively affects the process.

According to the studies reviewed, it was observed that there are more benefits than difficulties in the implementation of the standard. However there are much more complex certifications than ISO 14001, so for a company with a desire to improve their environmental management, the implementation of ISO 14001 is an initial step.

Whereas, the impact on financial performance and organizational performance proved positive, as certified companies not only attract more customers but also "stakeholders" which contributes to their organizational growth and increased competitiveness. And this greater competitiveness is essential to remain in the market.

The certifications for ISO 14001 and ISO 9001 can be treated not only as tactics to improve business performance, but also as standardization of social responsibility, as ISO 14001 regard environmental improvement and sustainability (Castka \& Balzarova, 2008). In addition, the industrial sectors with the two certifications have competitive advantage over other companies, since they have better profitability. Thus, the relation between the two standards proved positive and of great value to companies.

The current scenario provides evidence that customers have a preference for "green" production standards, so companies certified with ISO 14001 are more likely to work monitoring their environmental performance. This type of monitoring is also associated with an increased likelihood of regulatory compliance. This reflects the concern with "green washing", presenting an environmentally friendly face without changing actual behaviour and attracting more customers.

The concern in adopting the certification, which already existed in the European and Asian continent, is spreading to other continents. This is reflected in the increasing number of current certifications, showing a trend that in most countries continue to increase.

The concern for environmental management and quality management reflects to the market the companies that comply with tax regulations and that have stable technologies. Currently, the more a company shows their efficient management, the better the quality of their processes and the outcome of their products, i.e. a company that manages to have a sustainable production, follows the rules and satisfies their customers, and therefore has an efficient management system, is essential for everyone involved with the company and not only for the profitable party. 
Future work on the subject of environmental management may include a comparison of the ISO 14001 certification with other more complex certifications that are adopted by multinational companies instead of ISO standards, as the Eco-Management and Audit Scheme (EMAS), primarily used in Europe (Murmura et al., 2018).

Another suggestion would be to expand the study to other commonly used international databases such as ScienceDirect, Scopus and Web of Science, and focus in Asian countries as China, India and Japan, where ISO 14001 has been showing promising growth, despite the smaller number of publications in the subject.

\section{References}

Agan, Y., Acar, M. F., \& Borodin, A. (2013). Drivers of environmental processes and their impact on performance: a study of Turkish SMEs. Journal of Cleaner Production, 51, 23-33. http://dx.doi.org/10.1016/j.jclepro.2012.12.043.

Aiyub, K., Jahi, J. M., Arifin, K., \& Awang, A. (2009). Environmental performance in Small and Medium Sized Enterprises (SMEs) certified to ISO 14001 in the United Kingdom. International Business Management, 3, 7-14.

Alemagi, D., Oben, P., \& Ertel, J. (2006). Implementing environmental management systems in industries along the Atlantic coast of Cameroon: Drivers, benefits and barriers. Corporate Social Responsibility and Environmental Management, 13(4), 221-232. http:// dx.doi.org/10.1002/csr.106.

Arana-Landin, G., \& Heras-Saizarbitoria, 1. (2011). Paving the way for the ISO 14006 ecodesign standard: an exploratory study in Spanish companies. Journal of Cleaner Production, 19(9-10), 1007-1015. http://dx.doi.org/10.1016/j.jclepro.2011.01.013.

Arifin, K., Jahi, J. M., Razman, M. R., Aiyub, K., Awang, A., \& Ngah, M. S. Y. C. (2013). Integrated management system: new approach for environmental management in Malaysia. Journal of Food Agriculture and Environment, 11, 1400-1406.

Barkemeyer, R., Preuss, L., \& Lee, L. (2015). Corporate reporting on corruption: an international comparison (pp. 349-365). USA: Elsevier.

Bernardo, M., Casadesus, M., Karapetrovic, S., \& Heras, 1. (2009). How integrated are environmental, quality and other standardized management systems? An empirical study. Journal of Cleaner Production, 178), 742-750. http://dx.doi.org/10.1016/j.jclepro.2008.11.003.

Bernardo, M., Casadesús, M., Karapetrovic, S., \& Heras, 1. (2012). Do integration difficulties influence management system integration levels? Journal of Cleaner Production, 21(1), 23-33. http://dx.doi.org/10.1016/j.jclepro.2011.09.008.

Borella, l. L., \& Naime, R. (2012). Transformar a gestão ambiental integrada em vantagem competitiva. Revista Eletrônica em Gestão, Educação e Tecnologia Ambiental, 6, 1025-1042.

Brendler, E., \& Brandli, L. L. (2011). Integração do Sistema de Gestão Ambiental no sistema de gestão de qualidade em um indústria de confecções. Gestão \& Produção, 18(1), 27-40. http://dx.doi.org/10.1590/S0104-530X2011000100003.

Burgess, K., Singh, P. J., \& Koroglu, R. (2006). Supply chain management: a structured literature review and implications for future research. International Journal of Operations \& Production Management, 26(7), 703-729. http://dx.doi.org/10.1108/01443570610672202.

Campos, L. M. S. (2012). Environmental management systems (EMS) for small companies: a study in Southern Brazil. Journal of Cleaner Production, 32, 141-148. http://dx.doi.org/10.1016/j.jclepro.2012.03.029.

Cañón-De-Francia, J., \& Garcés-Ayerbe, C. (2009). ISO 14001 environmental certification: a sign valued by the market? Environmental and Resource Economics, 44(2), 245-262. http://dx.doi.org/10.1007/s10640-009-9282-8.

Carnevalli, J. A., \& Miguel, P. A. C. (2007). Revisão, análise e classificação da Literatura sobre o QFD- tipos de pesquisa, dificuldades de uso e benefícios do método. Gestão \& Produção, 14(3), 557-579. http://dx.doi.org/10.1590/S0104-530X2007000300011.

Casadesús, M., Marimon, F., \& Heras, 1. (2009). ISO 14001 diffusion after the success of the 1509001 model. Journal of Cleaner Production, 16(16), 1741-1754. http://dx.doi.org/10.1016/j.jclepro.2007.11.002.

Castka, A. P., \& Balzarova, M. A. (2008). The impact of $1 S 09000$ and 15014000 on standardisation of social responsibility-an inside perspective. International Journal of Production Economics, 113(1), 74-87. http://dx.doi.org/10.1016/j.ijpe.2007.02.048.

Castka, P., \& Prajogo, D. (2013). The effect of pressure from secondary stakeholders on the internalization of 1S0 14001. Journal of Cleaner Production, 47, 245-252. http://dx.doi.org/10.1016/j.jclepro.2012.12.034.

Chan, W. W. (2010). Environmental measures for hotels' environmental management systems: 1S0 14001. International Journal of Contemporary Hospitality Management, 21(5), 542-560. http://dx.doi.org/10.1108/09596110910967791.

Chavan, M. (2005). An appraisal of environment management systems: A competitive advantage for small businesses. Management of Environmental Quality, 16(5), 444-463. http://dx.doi.org/10.1108/14777830510614321.

Crowder, M. (2013). Quality standards: integration within a bereavement environment. The TQM Journal, 25(1), 18-28. http://dx.doi. org/10.1108/17542731311286405.

de Vries, H. J., Bayramoglu, D. K., \& van der Wiele, T. V. D. (2012). Business and environmental impact of ISO 14001. International Journal of Quality \& Reliability Management, 29(4), 425-435. http://dx.doi.org/10.1108/02656711211224866.

Disterheft, A., Caeiro, S. S. F. S., Ramos, M. R., \& Azeiteiro, U. M. M. (2012). Environmental Management Systems (EMS) implementation processes and practices in European higher education institutions- Top-down versus participatory approaches. Journal of Cleaner Production, 31, 80-90. http://dx.doi.org/10.1016/j.jclepro.2012.02.034.

Eng Ann, G. E., Zailani, S., \& Wahid, N. A. (2006). A study on the impact of environmental management system (EMS) certification towards firms' performance in Malaysia. Management of Environmental Quality, 17(1), 73-93. http://dx.doi.org/10.1108/14777830610639459.

Escanciano, C., Fernández, E., \& Vásquez, C. (2001). ISO 9000 certification and quality management in Spain: results of a national survey. The TQM Magazine, 2(3), 192-200. http://dx.doi.org/10.1108/09544780110385500.

Feil, A. A., Strasburg, V.J., \& Naime, R.H. (2013). Análise sobre as normas e indicadores de sustentabilidade e sua integração para gestão corporativa. Perspectiva em Gestão \& Conhecimento, 2, 21-36.

Ferron, R. T., Funchal, B., Nossa, V., \& Teixeira, A. J. C. (2012). Is $1 S 014001$ certification effective? An experimental analysis of firm profitability. Brazilian Administration Review, 9(spe), 78-94. http://dx.doi.org/10.1590/S1807-76922012000500006. 
Ferrón-Vílchez, V. (2016). Does symbolism benefit environmental and business performance in the adoption of 1S0 14001? Journal of Environmental Management, 183(Pt 3), 882-894. http://dx.doi.org/10.1016/j.jenvman.2016.09.047. PMid:27666644.

Fortuński, B. (2008). Does the environmental management standard ISO 14001 stimulate sustainable development?: An example from the energy sector in Poland. Management of Environmental Quality, 19(2), 204-212. http://dx.doi.org/10.1108/14777830810856582.

Franchetti, M. (2011). ISO 14001 and solid waste generation rates in US manufacturing organizations: an analysis of relationship. Journal of Cleaner Production, 19(9-10), 1104-1109. http://dx.doi.org/10.1016/j.jclepro.2011.01.004.

Gavronski, l., Ferrer, G., \& Paiva, E. L. (2008). ISO 14001 certification in Brazil: motivations and benefits. Journal of Cleaner Production, 16(1), 87-94. http://dx.doi.org/10.1016/j.jclepro.2006.11.002.

Gavronski, l., Paiva, E. L., Teixeira, R., \& Andrade, M. C. F. (2013). ISO 14001 certified plants in Brazil - taxonomy and practices. Journal of Cleaner Production, 39, 32-41. http://dx.doi.org/10.1016/j.jclepro.2012.08.025.

Godinho Filho, M., \& Fernandes, F. C. F. (2003). Um sistema para classificar e codificar os trabalhos que relacionam o controle da produção e o controle da qualidade. Gestão \& Produção, 10(1), 89-107. http://dx.doi.org/10.1590/S0104-530X2003000100007.

Godinho Filho, M., \& Fernandes, F. C. F. (2004). Manufatura enxuta: uma revisão que classifica e analisa os trabalhos apontando perspectivas de pesquisas futuras. Gestão \& Produção, 11(1), 1-19. http://dx.doi.org/10.1590/S0104-530X2004000100002.

Godinho Filho, M., Fernandes, F. C. F., \& Lima, A. D. (2009). Pesquisa em Gestão da Produção na indústria de calçados: revisão, classificação e análise. Gestão \& Produção, 16(2), 163-186. http://dx.doi.org/10.1590/S0104-530X2009000200002.

Gomez, A., \& Rodriguez, M. A. (2011). The effect $1 S 014001$ certification on toxic emissions: an analyses of industrial facilities in the north of Spain. Journal of Cleaner Production, 19(9-10), 1091-1095. http://dx.doi.org/10.1016/j.jclepro.2011.01.012.

González, P., Sarkis, J., \& Adenso-Díaz, B. (2008). Environmental management system certification and its influence on corporate practices: evidence from the automotive industry. International Journal of Operations \& Production Management, 28(11), 10211041. http://dx.doi.org/10.1108/01443570810910179.

Govindan, K., Diabat, A., \& Shankar, M. (2014). Analyzing the drivers of green manufacturing with fuzzy approach. Journal of Cleaner Production, 96, 182-193. http://dx.doi.org/10.1016/j.jclepro.2014.02.054.

Grael, P. F. F., \& Oliveira, O. J. (2009). Sistemas certificáveis de gestão ambiental e da qualidade: praticas para integração em empresas do setor moveleiro. Produção, 4, 1-12.

Granly, B. M., \& Welo, T. (2013). EMS and sustainability: experiences with ISO 14001 and Eco-Lighthouse in Norwegian metal processing SMEs. Journal of Cleaner Production, 64, 1-11.

Griffith, A., \& Bhutto, K. (2008). Improving environmental performance through integrated management systems (IMS) in the UK. Management of Environmental Quality, 19(5), 565-578. http://dx.doi.org/10.1108/14777830810894247.

Guoyou, Q., Saixing, Z., Xiadong, L., \& Chiming, T. (2012). Role of internalization process in defining the relationship between 150 14001 certification and corporate environmental performance. Corporate Social Responsibility and Environmental Management, 19(3), 129-140. http://dx.doi.org/10.1002/csr.258.

Halila, F., \& Tell, J. (2013). Creating synergies between SMEs and universities for ISO 14001 certification. Journal of Cleaner Production, 48, 85-92. http://dx.doi.org/10.1016/j.jclepro.2012.11.014.

Hayam, W. (2010). How do institutional shareholders manipulate corporate environmental strategy to protect their equity value? A study of the adoption of ISO 14001 by egyptian firms. Business Strategy and the Environment, 19(8), 495-511. http://dx.doi. org/10.1002/bse.654.

Heras-Saizarbitoria, 1., \& Arana, G. (2010). Alternative models for environmental management in SMEs: the case of Ekoscan vs. ISO 14001. Journal of Cleaner Production, 18(8), 726-735. http://dx.doi.org/10.1016/j.jclepro.2010.01.005.

Heras-Saizarbitoria, 1., \& Landín, G. A. (2011). Impacto de la certificacion ISO 14001 en el rendimiento financiero empresarial: conclusiones de un estudio empírico. Cuadernos de Economía y Dirección de la Empresa, 14(2), 112-122. http://dx.doi.org/10.1016/j. cede.2011.02.002.

Heras-Saizarbitoria, 1., Dogui, K., \& Boiral, O. (2013). Shedding light on ISO 14001 certification audits. Journal of Cleaner Production, 51, 88-98. http://dx.doi.org/10.1016/j.jclepro.2013.01.040.

Heras-Saizarbitoria, 1., Landín, G. A., \& Molina-Azorín, J. F. (2011a). Do drivers matter for the benefits of 1S0 14001? International Journal of Operations \& Production Management, 31(2), 192-216. http://dx.doi.org/10.1108/01443571111104764.

Heras-Saizarbitoria, 1., Molina-Azorín, J. F., \& Dick, G. P. M. (2011b). ISO 14001 certification and financial performance: selection-effect versus treatment-effect. Journal of Cleaner Production, 19(1), 1-12. http://dx.doi.org/10.1016/j.jclepro.2010.09.002.

Hikichi, S. E., Salgado, E. G., \& Beijo, L. A. (2016). Characterization of dissemination of ISO 14001 in countries and economic sectors in the Americas. Journal of Environmental Planning and Management, 60(9), 1554-1574. https://doi.org/10.1080/09640568.20 16.1240070 .

Hojnik, J., \& Ruzzier, M. (2017). Does it pay to be eco? The mediating role of competitive benefits and the effect of 1S014001. European Management Journal, 5(5), 581-594. http://dx.doi.org/10.1016/j.emj.2017.07.008.

Hwee-Nga, J. K. (2009). The influence of ISO 14000 on firm performance. Social Responsibility Journal, 5(3), 408-422. http://dx.doi. $\operatorname{org} / 10.1108 / 17471110910977311$

latridis, K., \& Kesidou, E. (2018). What drives substantive versus symbolic implementation of ISO 14001 in a time of economic crisis? Insights from Greek manufacturing companies. Journal of Business Ethics, 148(4), 859-877. http://dx.doi.org/10.1007/s10551016-3019-8.

International Organization for Standardization. (2015). Recuperado em 13 de março de 2015, de http://www.iso.org/iso/home.html

Iraldo, F., Testa, F., \& Frey, M. (2009). Is an environmental management system able to influence environmental and competitive performance? The case of the eco-management and audit scheme (EMAS) in the European union. Journal of Cleaner Production, 17(16), 1444-1452. http://dx.doi.org/10.1016/j.jclepro.2009.05.013.

Jurincic, 1., \& Bojnec, S. (2009). Environmental Management in Slovenian tourist enterprises. International Journal of Sustainable Development and Planning, 4(3), 226-237. http://dx.doi.org/10.2495/SDP-V4-N3-226-237. 
Kadasah, N. A. (2013). Attitudes of managers towards the potential effects of $1 S 014001$ in Saudi Arabia: factor analysis. International Business Research, 6(7), 91-101. http://dx.doi.org/10.5539/ibr.v6n7p91.

Karapetrovic, S., \& Casadesús, M. (2009). Implementing environmental with other standardized management systems: scope, sequence, time and integration. Journal of Cleaner Production, 17(5), 533-540. http://dx.doi.org/10.1016/j.jclepro.2008.09.006.

Kehbila, A. G., Ertel, J., \& Brent, A. C. (2009). Strategic corporate environmental management within the South African automotive industry: motivations, benefits, hurdles. Corporate Social Responsibility and Environmental Management, 16(6), 310-323. http:// dx.doi.org/10.1002/csr.188.

King, A. A., Lenox, M. J., \& Terlaak, A. (2005). The strategic use of decentralized institutions: exploring certification with the 1SO 14001 management standard. Academy of Management Journal, 48(6), 1091-1106. http://dx.doi.org/10.5465/amj.2005.19573111.

Lagodimos, A. G., Chountalas, P. T., \& Chatzi, K. (2007). The state of ISO 14001 certification in Greece. Journal of Cleaner Production, 15(18), 1743-1754. http://dx.doi.org/10.1016/j.jclepro.2006.06.015.

Link, S., \& Naveh, E. (2006). Standardization and discretion: does the environmental standard ISO 14001 lead to performance benefits? Engineering Management, 53, 508-519.

Liyin, S., Hong, Y., \& Griffith, A. (2006). Improving environmental performance by means of empowerment of contractors. Management of Environmental Quality, 17(3), 242-257. http://dx.doi.org/10.1108/14777830610658674.

Marimon, F., Casadesus, M., \& Heras, 1. (2010). Certification intensity level of the leading nations in ISO 9000 and ISO 14000 standards. International Journal of Quality \& Reliability Management, 27(9), 1002-1020. http://dx.doi.org/10.1108/02656711011084800.

Marimon, F., Heras, 1., \& Casadesus, M. (2009). ISO 9000 and ISO 14000 standards: a projection model for the decline phase. Total Quality Management \& Business Excellence, 20(1), 1-21. http://dx.doi.org/10.1080/14783360802614257.

Massoud, M. A., Fayad, R., Kamleh, R., \& El-Fadel, M. (2010). Environmental management system (ISO 14001) certification in developing countries: challenges and implementation strategies. Environmental Science \& Technology, 44(6), 1884-1887. http:// dx.doi.org/10.1021/es902714u. PMid:20151632.

Matuszak-Fleijsman, A. (2009). Benefits of environmental management system in polish companies compliant with ISO 14001 . Polish Journal of Environmental Studies, 18, 411-419.

McGuire, W. (2014). The effect of ISO 14001 on environmental regulatory compliance in China. Ecological Economics, 105, $254-264$. http://dx.doi.org/10.1016/j.ecolecon.2014.06.007.

Moreira, A. P. (2004). Sistema de Gestão Ambiental (SGA) e a ISO 14001. Um estudo de caso. Florianópolis: Curso de Pós-Graduação em Administração, Universidade Federal de Santa Catarina.

Murmura, F., Liberatore, L., Bravi, L., \& Casolani, N. (2018). Evaluation of ltalian companies' perception about ISO 14001 and eco management and audit scheme 1ll: motivations, benefits and barriers. Journal of Cleaner Production, 174, 691-700. http://dx.doi. org/10.1016/j.jclepro.2017.10.337.

Nakano, D., \& Muniz Junior, J. (2018). Writing the literature review for empirical papers. Production, 28, e20170086. http://dx.doi. org/10.1590/0103-6513.20170086.

Naveh, E., Marcus, A., \& Moon, H. (2005). Implementing ISO 9000. Performance improvement by first and second movers. International Journal of Production, 42(9), 1843-1853. http://dx.doi.org/10.1080/00207540410001662912.

Nawrock, D., Brorson, T., \& Lindhqvist, T. (2009). ISO 14001 in environmental supply chain practices. Journal of Cleaner Production, 17, 1434-1443.

Newbold, J. (2006). Chile's environmental momentum: ISO 14001 and the large-scale mining industry and case studies from the state and private sector. Journal of Cleaner Production, 14(3-4), 248-261. http://dx.doi.org/10.1016/j.jclepro.2004.05.010.

Nguyen, Q. A., \& Hens, L. (2013). Environmental performance of the cement industry in Vietnam: the influence of ISO 14001 certification. Journal of Cleaner Production, 1, 1-17.

Nishitani, K. (2009). An empirical study of the initial adoption of ISO 14001 in Japanese manufacturing firms. Ecological Economics, 68(3), 669-679. http://dx.doi.org/10.1016/j.ecolecon.2008.05.023.

Oliveira, G. T., \& Martins, R. A. (2008). Efeitos da adoção do modelo do Prêmio Nacional da Qualidade na medição de desempenho: estudos de caso em empresas ganhadoras do prêmio. Gestão \& Produção, 15(2), 247-259. http://dx.doi.org/10.1590/S0104530X2008000200004.

Oliveira, O. J., \& Pinheiro, C. R. M. S. (2009). Best practices for the implantation of 1S0 14001 norms: a study of change management in two industrial companies in the Midwest region of the state of São Paulo - Brazil. Journal of Cleaner Production, 17(9), 883885. http://dx.doi.org/10.1016/j.jclepro.2008.12.008.

Oliveira, O. J., \& Serra, J. R. (2010). Benefícios e dificuldades da gestão ambiental com base na 1 SO 14001 em empresas industriais de São Paulo. Production, 20(3), 429-438. http://dx.doi.org/10.1590/S0103-65132010005000013.

Oliveira, O. J., Serra, J. R., \& Salgado, M. H. (2010). Does ISO 14001 work in Brazil? Journal of Cleaner Production, 1(18), 1797-1806. http://dx.doi.org/10.1016/j.jclepro.2010.08.004.

Orcos, R., Pérez-Aradros, B., \& Blind, K. (2018). Why does the diffusion of environmental management standards differ across countries? The role of formal and informal institutions in the adoption of 150 14001. Journal of World Business, 53(6), 850-861. https://doi. org/10.1016/j.jwb.2018.07.002.

Paulraj, A., \& Jong, P. (2011). The effect of ISO 14001 certification announcements on stock performance. International Journal of Operations \& Production Management, 31(7), 765-788. http://dx.doi.org/10.1108/01443571111144841.

Potoski, M., \& Prakash, A. (2005). Green clubs and voluntary governance: 1 SO 14001 and firms' regulatory compliance. American Journal of Political Science, 49(2), 235-248. http://dx.doi.org/10.1111/j.0092-5853.2005.00120.x.

Prajogo, D., Tang, A. K. Y., \& Lai, K. (2012). Do firms get what they want from ISO 14001 adoption?: an Australian perspective. Journal of Cleaner Production, 33, 117-226. http://dx.doi.org/10.1016/j.jclepro.2012.04.019.

Preston, L. E., \& O'Bannon, D. P. (1997). The corporate social-financial performance relationship. Business \& Society, 36(4), 419-429. http://dx.doi.org/10.1177/000765039703600406. 
Psomas, E. L., Fotopoulos, C. V., \& Kafetzopoulos, D. P. (2011). Motives, difficulties and benefits in implementing the ISO 14001 Environmental Management System. Management of Environmental Quality, 22(4), 502-521. http://dx.doi.org/10.1108/14777831111136090.

Ratnasingam, J., \& Wagner, K. (2010). The impact of 15014001 on the operations management of wooden furniture manufacturers in Malaysia. European Journal of Wood and Wood Products, 68(4), 479-481. http://dx.doi.org/10.1007/s00107-009-0370-9.

Rodriguez, G., Alegre, F. J., \& Martínez, G. (2011). Evaluation of environmental management resources (ISO 14001) at civil engineering construction worksites: a case study of the community of Madrid. Journal of Environmental Management, 92(7), 1858-1866. http:// dx.doi.org/10.1016/j.jenvman.2011.03.008. PMid:21459507.

Sakr, D. A., Sherif, A., \& El-Haggar, S. M. (2010). Environmental management systems' awareness: an investigation of top 50 contractors in Egypt. Journal of Cleaner Production, 18(3), 210-218. http://dx.doi.org/10.1016/j.jclepro.2009.09.021.

Salgado, E. G., Salomon, V. A., Mello, C. H. P., Fass, F. D. M., \& Xavier, A. F. (2010). Modelos de referências para o desenvolvimento de produtos: classificação, análises e sugestões para pesquisas futuras. Revista Produção Online, 10(4), 886-911. http://dx.doi. org/10.14488/1676-1901.v10i4.520.

Sambasivan, M., \& Fei, N. Y. (2008). Evaluation of critical success factors of implementation of ISO 14001 using analytic hierarchy process (AHP): a case study from Malaysia. Journal of Cleaner Production, 16(13), 1424-1433. http://dx.doi.org/10.1016/j.jclepro.2007.08.003.

Santos, G., Mendes, F., \& Barbosa, J. (2011). Certification and integration of management systems: the experience of Portuguese smal and medium enterprises. Journal of Cleaner Production, 19(17-18), 1965-1974. http://dx.doi.org/10.1016/j.jclepro.2011.06.017.

Santos, G., Rebelo, M., Barros, S., \& Pereira, M. (2012). Certification and integration of environment with quality and safety-A path to sustained success. In S. Curkovic (Ed.), Sustainable development-authoritative and leading edge content for environmental management (Vol. 1, pp. 193-218). Croatia: Sime Curkovic, InTech http://dx.doi.org/10.5772/48414.

Schylander, E., \& Martinuzzi, A. (2007). ISO 14001-experiences, effects and future challenges: a National Study in Austria. Business Strategy and the Environment, 16(2), 133-147. http://dx.doi.org/10.1002/bse.473.

Seijo-García, M. A., Filgueira-Vizoso, A., \& Muñoz-Camacho, E. (2013). Consecuencias positivas de la implantación de la certificación ISSO 14001 en las empresas Gallegas (España). Dyna (Bilbao), 177, 13-21.

Silveira, M. P., Alvez, J. N., \& Flaviano, V. (2013). Os desafios da implantação de um sistema de gestão ambiental: estudo de caso em uma indústria de laticínios. Revista Gestão \& Sustentabilidade Ambiental, 2(2), 88-106. http://dx.doi.org/10.19177/rgsa.v2e2201388-106.

Simon, A., \& Douglas, A. (2013). Integration management systems: does the location matter? International Journal of Quality \& Reliability Management, 30(6), 675-689. http://dx.doi.org/10.1108/02656711311325629.

Simon, A., Bernardo, M., Karapetrovic, S., \& Casadesús, M. (2011). Integration of standardized environmental and quality management systems audits. Journal of Cleaner Production, 19(17-18), 2057-2065. http://dx.doi.org/10.1016/j.jclepro.2011.06.028.

Simon, A., Karapetrovic, S., \& Casadesús, M. (2012). Difficulties and benefits of integrated management systems. Industrial Management \& Data, 112(5), 828-846. http://dx.doi.org/10.1108/02635571211232406.

Souza, M. T. S., Machado Júnior, C., \& Furlaneto, C. J. (2010). Panorama de consumo de energia elétrica e de fontes alternativas. Journal of the Health Sciences Institute, 28, 215-223.

Stevens, P. A., Batty, W. J., Longhurst, P. J., \& Drew, G. H. (2012). A critical review of classification of organisations in relation to the voluntary implementation of environmental management systems. Journal of Environmental Management, 113, 206-212. http:// dx.doi.org/10.1016/j.jenvman.2012.08.037. PMid:23037315.

Takahashi, T., \& Nakamura, M. (2010). The impact of operational characteristics on firms' EMS decisions: Strategic adoption of ISO 14001 certifications. Corporate Social Responsibility and Environmental Management, 17, 215-229.

Tan, L. P. (2005). Implementing ISSO 14001: is it beneficial for firms in newly industrialized Malaysia? Journal of Cleaner Production, 13(4), 397-404. http://dx.doi.org/10.1016/j.jclepro.2003.12.002.

Tarí, J. J., Molina-Azorín, J. F., \& Heras, 1. (2012). Benefits of the ISO 9001 and ISO 14001 standards: A literature review. Journal of Industrial Engineering and Management, 5(2), 297-322. http://dx.doi.org/10.3926/jiem.488.

Tsai, W. H., \& Chou, W. C. (2009). Selecting management systems for sustainable development in SMEs: A novel hybrid model based on DEMATEL, ANP, and ZOGP. Expert Systems with Applications, 36(2), 1444-1458. http://dx.doi.org/10.1016/j.eswa.2007.11.058.

Turk, A. M. (2009). The benefits associated with 15014001 certification for construction firms: Turkish case. Journal of Cleaner Production, 175), 559-569. http://dx.doi.org/10.1016/j.jclepro.2008.11.001.

Turner, 1. (2009). Measuring performance: environmental management systems. Sustainability of Activities in Zoos and Aquariums, 43, 82-90.

Whitford, A. \& Tucker, J.A. (2012). Focal points in Public Policy: evidence from voluntary regulation. Review of Policy Research, 29 , 281-299.

Yin, H., \& Ma, C. (2009). International integration: a hope for a greener China? International Marketing Review, 26(3), 348-367. http://dx.doi.org/10.1108/02651330910960825.

Yin, H., \& Schmeidler, P. J. (2009). Why do standardized ISO 14001 environmental management systems lead to heterogeneous environmental outcomes? Business Strategy and the Environment, 18(7), 469-486. http://dx.doi.org/10.1002/bse.629.

Zeng, S. X., Tam, C. M., Tam, V. W., \& Deng, Z. M. (2005). Towards implementation of $1 S 014001$ environmental management systems in selected industries in China. Journal of Cleaner Production, 13(7), 645-656. http://dx.doi.org/10.1016/j.jclepro.2003.12.009.

Zeng, S. X., Tam, V. W., \& Le, K. N. (2008). Towards effectiveness of integrated systems for enterprises. The Engineering Economist, 21, 171-179.

Zhang, W., Wang, W., \& Wang, S. (2013). Environmental performance evaluation of implementing EMS (ISO 14001) in the coating industry: case study of a Shanghai coating firm. Journal of Cleaner Production, 64, 205-217. http://dx.doi.org/10.1016/j.jclepro.2013.08.028.

Ziegler, A., \& Seijas Nogareda, J. (2009). Environmental management systems and technological environmental innovations: Exploring the causal relationship. Research Policy, 38(5), 885-893. http://dx.doi.org/10.1016/j.respol.2009.01.020.

Zobel, T. (2013). ISO 14001 certification in manufacturing firms: a tool for those in need or an indication of greenness? Journal of Cleaner Production, 43, 37-44. http://dx.doi.org/10.1016/j.jclepro.2012.12.014. 